\title{
Population dynamics of Trichodactylus borellianus (Crustacea Decapoda Brachyura) and interactions with the aquatic vegetation of the Paraná River (South America, Argentina)
}

\author{
P.A. Collins, F. Giri, V. Williner*
}

Instituto Nacional de Limnología (INALI-CONICET-UNL), José Maciá 1933, 3016 Santo Tomé, Santa Fe, Argentina

\begin{abstract}
Animal populations have a certain synchronization between their fluctuations and the environmental factors which have a direct influence on density, sex ratio and recruitment. Trichodactylus borellianus is a common freshwater crab of the Trichodactylidae family, originary from South America. This crab is omnivorous and grazes upon the littoral communities. The present study is the first analysis of the natural distribution and population dynamics of freshwater crabs in La Plata Basin (Argentina) and their relationship with certain abiotic and biotic parameters. It was carried out in three environments (riverine zone of streams and river) of the Paraná River floodplain. Crab populations were sampled monthly from August 2001 to October 2002. The mean crab abundance among the study sites was significantly different, being lower in samples from the environment surrounding the principal channel of the Paraná River. Crab density showed two peaks: the highest occurred during late winter and early spring, and the lowest during late summer. Males were only more abundant in late winter and spring. In spring, summer and autumn, the population showed a contagious distribution. The population displayed a regular arrangement in winter. From mid-spring to mid-autumn juveniles were very frequent whereas adults predominated the rest of the year. Total crab number in the stream nearest to the main channel varied according to the level and temperature of the river. In the other sites, located further from the main channel of the Paraná River, crab numbers and vegetation biomass showed a more similar arrangement with a higher correlation.
\end{abstract}

Keywords : crabs, Paraná River floodplain, population ecology, flood pulse, South America.

\section{Introduction}

Populations are dynamic in space and time. Abundance of organisms can increase or decrease, having a similar influence on the density-dependent processes and the stochastic events (Morris 1996). Moreover, animal populations have certain synchronization between their fluctuations and the different environmental factors (Ranta 1998, Ruetz et al. 2005) which have a direct influence on density, sex ratio and recruitment. The study of biotic interrelationships such as those occurring in planktonic groups or those of invertebrates living in macrophytes, requires the knowledge of

\footnotetext{
* Corresponding author :

E-mail:wvero@arnet.com.ar
}

change rate, response time and the possibility for a population or community to repeat these conditions through time (Poi de Neiff \& Bruquetas 1989). In rivers with floodplains, such us the Paraná River, different highly dynamic habitats are recognizable, where stability and diversity are primarily conditioned by hydrology and flow of materials. The flooding pulse results in the coupling between the river and floodplain. Moreover, this basin provide shelters, foods and connectivity among different waterbodies (Bonetto \& Wais 1995). Therefore, relationships among populations of aquatic organisms like crabs, are subject to the variations of the river.

Trichodactylus borellianus is a common freshwater crab species of the Trichodactylidae family from South America (Lopretto 1995, Magalhães \& Türkay 1996). Its natural habitat is the aquatic vegetation -

Article available at http://www.limnology-journal.org or http://dx.doi.org/10.1051/limn/2006001 
mainly roots and leaves of Eicchornia - and objects in the sediment on the margins of shallow lakes, streams and rivers (Ringuelet 1949, Poi de Neiff \& Neiff 1980, Paporello 1987, Poi de Neiff \& Carignan 1997). This crab is widely distributed in Brazil (Pará, Mato Grosso, Mato Grosso do Sul), Bolivia, Paraguay and Argentina, mainly in the Paraná and Paraguay rivers (Magalhães 2003). Trichodactylus borellianus is omnivorous and grazes upon littoral communities (Williner \& Collins, unpublished). On the other hand, it is a diet component of fish, amphibians, birds and mammals (Bonetto et al. 1963, Oliva et al. 1981, Beltzer 1983, 1984, Beltzer \& Paporello 1984; Lajmanovich \& Beltzer 1993, Massoia 1976, Bianchini \& Delupi 1987), which indicates its important trophic role in the transfer of energy among littoral, lotic and non-aquatic communities. However, there are few studies on temporal and spatial scales upon the dynamics of natural populations in freshwater decapods crustaceans (Bueno \& Bond-Buckup 2000, Trigueirinho Alarcon et al. 2002). This study is the first analysis of the natural distribution and population dynamics of freshwater crabs in La Plata Basin and their relationship with certain abiotic and biotic parameters.

\section{Material and Methods}

\section{Study Area}

This study was carried out in three environments of the Paraná river according to a transect between the main channel and the floodplain. The sample sites were Santa Fe river $\left(\mathrm{S} 31^{\circ} 38^{\prime} 35^{\prime \prime}\right.$ 'W60 40 '05,5', at 18AMSL), Aliviador stream (S31 ${ }^{\circ} 40^{\prime} 17,9^{\prime \prime}$ 'W60 34' 45,9" at 20AMSL) and Las Sandias stream (S31 ${ }^{\circ} 41^{\prime}$ 15,3' 'W60'31'31,6" at 18AMSL) (Fig. 1). This river is the biggest channel of La Plata Basin, containing $85 \%$ of the total freshwater in Argentina. This system consists of a river with an alluvial valley ranging from approximately 13 to $56 \mathrm{~km}$ in width and a slope of $0.036 \mathrm{~m} \cdot \mathrm{km}^{-1}$. The main channel is located on the eastern margin. Its width varies between 2 and $4.2 \mathrm{~km}$, being $2.3 \mathrm{~km}$ wide in the study section (Paoli et al. 2000). The western area of the river has several secondary rivers, streams, ponds and islands, extended approximately $10 \mathrm{~km}$ in width to main channel.

The flow along the main channel varies between $10600 \mathrm{~m}^{3} \cdot \mathrm{s}^{-1}$ and $31000 \mathrm{~m}^{3} \cdot \mathrm{s}^{-1}$ causing a primary runoff in spring and summer (November to March), which originates annual floods. Autumn and winter are the low water seasons (Bonetto \& Wais 1995, Giacosa et al. 2000).
The flood pulse of the Paraná River is the dominant environmental factor producing changes in the chemical and physical conditions, and within the floodplain communities even in the lower reach of the tributaries. The littoral zones have abundant and diverse free-floating and emergent macrophytes like Eichhornia crassipes, E. azurea, Ricciocarpus natans, Ludwigia peploides, Paspalum repens and Salvinia herzogii which may cover extensive areas.

\section{Sampling}

Trichodactylus borellianus populations were sampled monthly from August 2001 to October 2002. Three random samples were taken using a hand net (area: $0.9 \mathrm{~m}^{2}$, and with mesh size of $1 \mathrm{~mm}$ ) below the aquatic vegetation at each site (Williner \& Collins 2002). The same effort was applied to all samples. Crabs and aquatic vegetation were put in plastic bags and transported to the laboratory for the subsequent separation of crabs from plants. Temperature, $\mathrm{pH}$, conductivity and dissolved oxygen were measured at each site. The river level was registered in Santa Fe port limnigraph.

\section{Laboratory analysis}

Crabs separated from aquatic plants were anaesthetized (cold $2-4{ }^{\circ} \mathrm{C}$ ) prior to their fixation in $70 \%$ ethanol. T. borellianus were identified and counted. Carapace

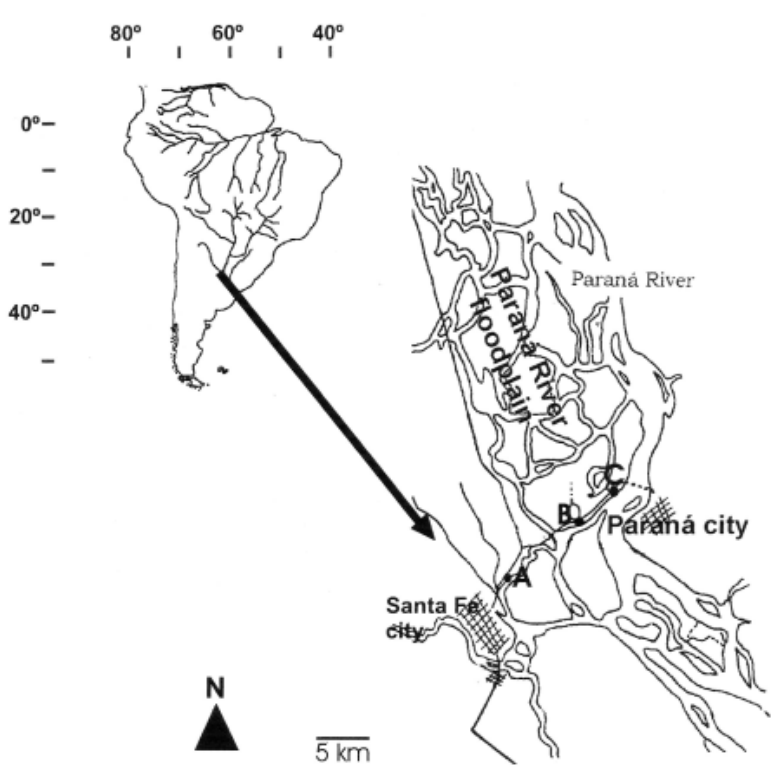

Fig.1. Location of sampling sites in the Paraná River floodplain : ASanta Fe River, B- Aliviador stream, and C- Las Sandias stream. 
width (CW; between first anterior spine carapace) was measured with a calliper under a stereomicroscope to the nearest $0.1 \mathrm{~mm}$. Individuals of $T$. borellianus were separated into females, males and juveniles considering the characteristics of their abdomen according to Lopretto (1976). The presence of ovigerous females was recorded at each sampling occasion. Aquatic plants were identified using a diagnostic key (Marta 1983) and weighed on a digital scale. Moist biomass of plant was recorded.

\section{Data analysis}

Normality and homoscedasticity were studied in the first place. Density and temporal variation were determined to ascertain their variations according to ANOVA. Relationships among sex ratio and river level, temperature and vegetation biomass were showed by correlation analyses. Kruskal-Wallis analysis was also performed to compare variation between males and females (Zar 1996). Crab spatial distribution was examined by calculation of Dispersion Index (variance: mean ratio) (Elliot 1977). Moreover, the relationship among crab density, vegetation biomass, temperature and river level were analysed by the Pearson Product Moment Correlation Coefficient and showed by Cluster analysis using UPGM linkage (Kovach 1998).

\section{Results}

Sample sites showed abundant aquatic vegetation, Eicchornia crassipes and E. azurea were the most abundant in all samples. In Santa Fe River E. crassipes and E. azurea represented $85.33 \pm 10.43 \%$, Salvinia sp. $7 \pm 7.51 \%$ and the rest of the percentage of others taxa (Limnobium sp., Azzolla sp., Pistia sp., Ludwigia sp., Paspalum repens, Hydrocotyle ranunculoides). Eicchornia crassipes and E. azurea showed $70 \pm 10.18 \%$ in Aliviador 1 streams, and $81.67 \pm 10.29 \%$ in Sandias streams and Salvinia sp $18.33 \pm 12.05 \%$ and $11 \pm 10.39$ $\%$ respectively. In both, the rest of the percentage was represented for Azzolla sp., Pistia sp., Ricciorcarpus sp., Ludwigia sp., Paspalum repens, and Hydrocotyle ranunculoides. The fluctuations of water level and temperature corresponded to the natural cycle. The conductivity of the sampling site were $143.3 \pm 30.55$ $\mu \mathrm{S} . \mathrm{cm}^{-1}$ in Santa Fe River, $120.0 \pm 36.06 \mu{\mathrm{S} . \mathrm{cm}^{-1}}^{-1}$ Aliviador 1 streams, and $113.1 \pm 11.55 \mu{\mathrm{S} . \mathrm{cm}^{-1}}^{-1}$ in Sandias streams. The $\mathrm{pH}$ and dissolved oxygen showed relatively constant values along time, being similar in all sites. The $\mathrm{pH}$ values were $7.5 \pm 0.12$ in Santa Fe River, $7.3 \pm 0.12$ in Aliviador 1 streams, and $7.3 \pm 0.23$ in San- dias streams. Dissolved oxygen concentration were $7.7 \pm 1.90$ mg. $\mathrm{l}^{-1}$ in Santa Fe River, $7.4 \pm 1.64 \mathrm{mg} . \mathrm{l}^{-1}$ in

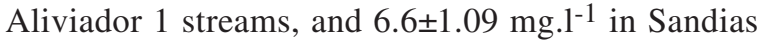
streams.

Trichodactylus borellianus showed high densities in the aquatic vegetation, mainly E. crassipes, throughout the year. During the sampling time, mean densities ranged from 170 to 0 crabs $\mathrm{m}^{-2}$ in Santa Fe River, 275 to 0 crabs.m $\mathrm{m}^{-2}$ in Aliviador 1 stream and 25 to 0 crabs.m-2 in Las Sandias stream. The mean crab abundance among the studied sites were significantly different, being lower in samples from the environment surrounding the principal channel of the Paraná river $\left(\mathrm{F}_{0.05}(1), 2.132=7.40, \mathrm{p}=0.0009\right)$. However, differences were not significant between Santa Fe river and Las Sandias stream (Tukey $\mathrm{p}>0.05$ ). Variations through months were not important in Santa Fe river $\left(\mathrm{F}_{0.05}(1), 14.42=0.80, \mathrm{p}=0.6602\right)$ but significant in Aliviador 1 stream $\left(\mathrm{F}_{0.05}(1), 14.42=3.23, \mathrm{p}=0.0034\right)$ and Las Sandias stream $\left(\mathrm{F}_{0.05}(1), 14.42=2.94, \mathrm{p}=0.0064\right)$ (Fig. 2). Crab density showed two peaks: the highest occurred during late winter and early spring, and the lowest during late summer, being the most evident in Aliviador 1 stream. Regarding the rest of the study period, density decreased in all sites (Figure 2) appearing to stabilize and fluctuate around an overall mean of $14.2 \pm 9.26$ in Santa Fe river, $33.4 \pm 33.9$ in Aliviador stream and $9.4 \pm 5.9$ in Las Sandias stream. Samples without crabs occurred in winter (May-June) (Fig. 2).

\section{Sex ratio}

A significantly greater number of females were observed in all samples. In general, males were only more abundant in late winter and spring (Fig. 3). Variations in the number of males and females during the study period showed a negative correlation with the level of the river (male: $r=-0.7638, p=0.0017$; female: $r=-0.7133, p=0.0028)$. However, other parameters (temperature, vegetation biomass) did not have a significant correlation with the presence of males or females. Nevertheless, the change in vegetation biomass showed a negative relationship with river level ( $\mathrm{r}=0.5379, \mathrm{p}=0.0386)$. Moreover, male and female rates had significantly positive variations $(r=0.9828$, $\mathrm{p}<0.0001$ ), being males the most fluctuating group among the three sampling sites (Kruskal-Wallis-ChiSquare $9.070 \mathrm{p}=0.011$ ).

Ovigerous females appeared in late winter (August), being present until March with a higher occurrence in November and January. 


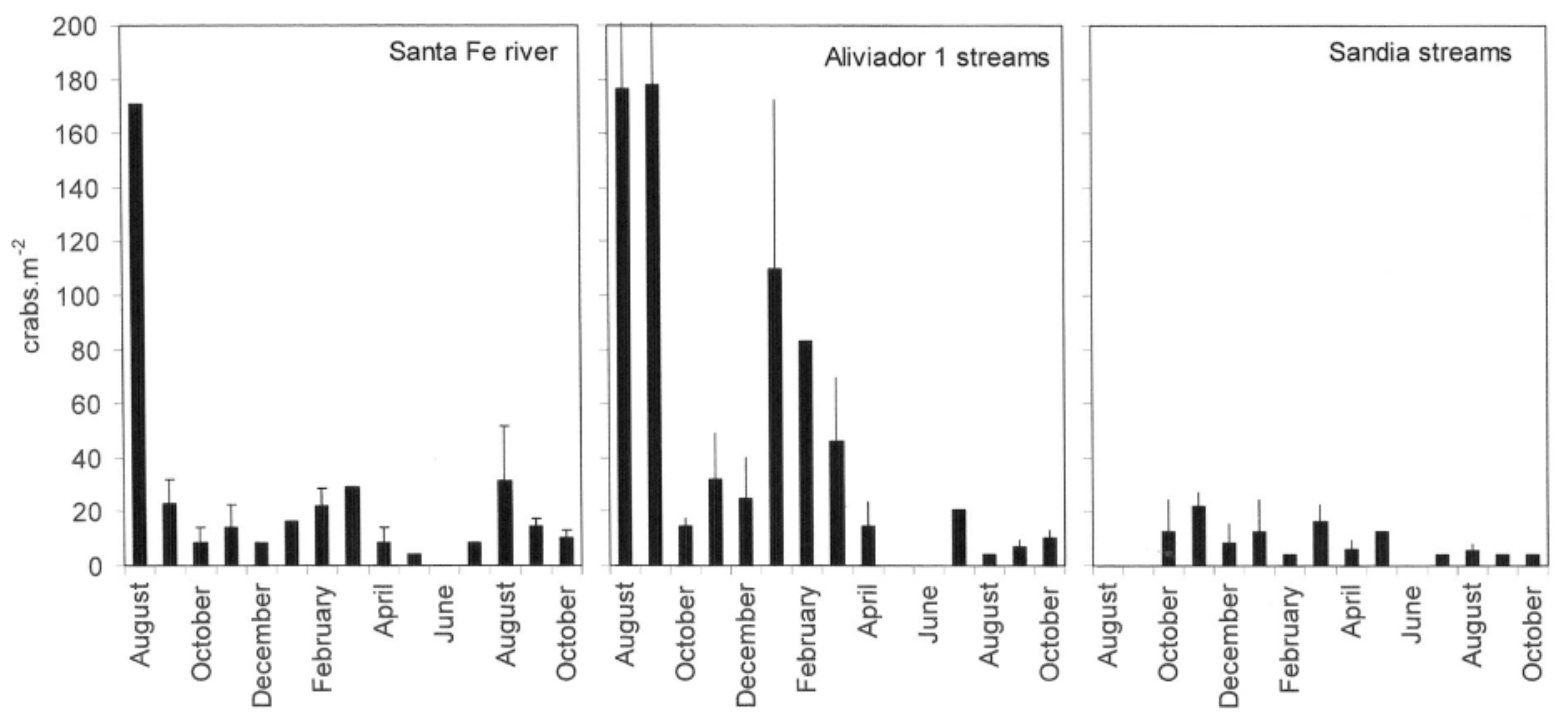

Fig. 2. Mean crab density (crabs.m-2) variations during sampling months (August 2001-October 2002).

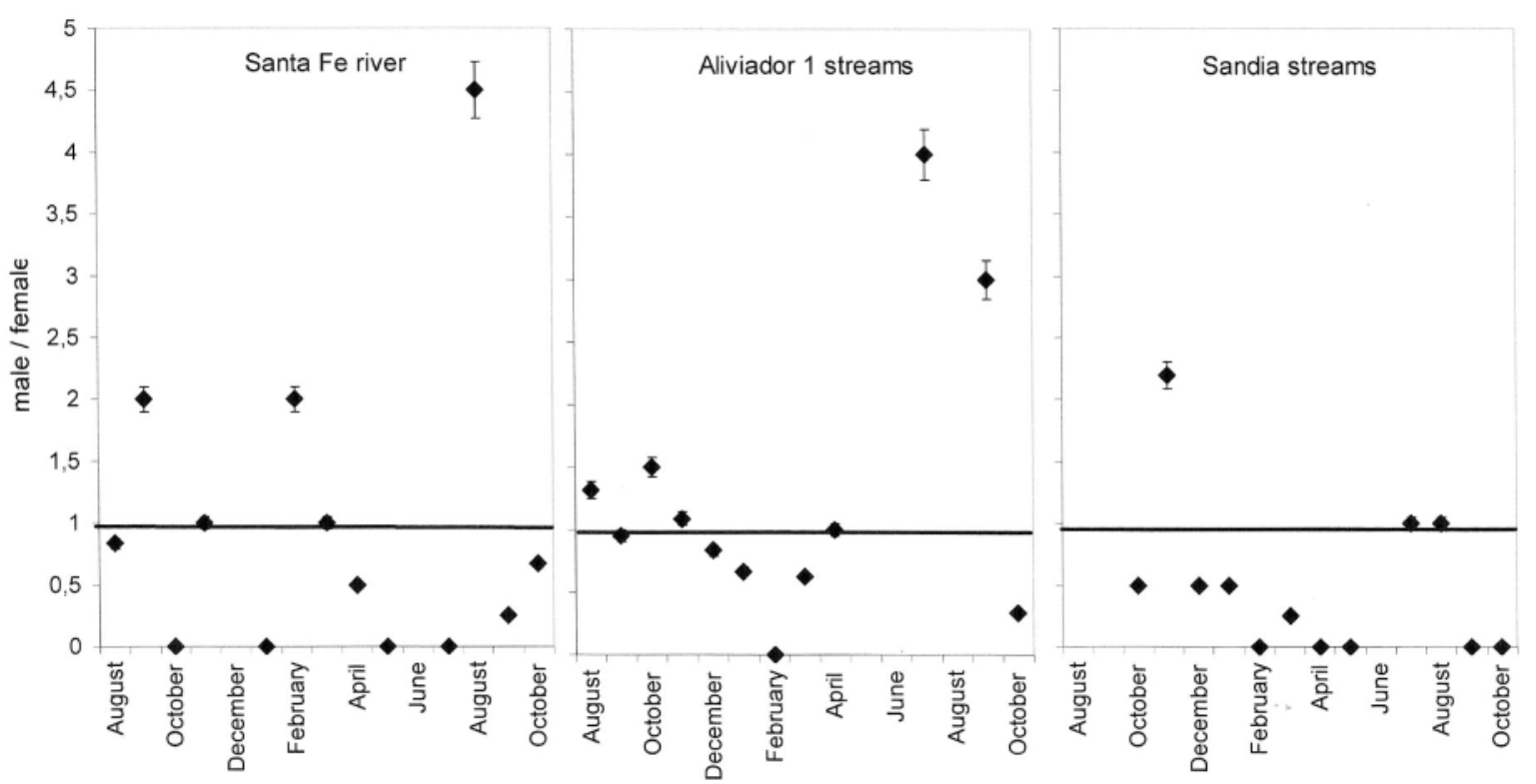

Fig. 3. Sex ratio of T. borellianus throughout the sampling periods.

Distribution of the population and relationship with the parameters measured

The population distribution of T. borellianus showed temporal variations but this did not appear to be significantly different $\left(\mathrm{F}_{0.05}(1), 2.44=1.24, \mathrm{p}=0.3459\right)$. In spring, summer and autumn, the population showed a contagious distribution (Dispersion Index: 3.64, 10.49, and 5.81 respectively). However, the population displayed a regular arrangement (0.77) in winter.

Crab size varied along the year $\left(\mathrm{F}_{0.05}(1), 2.38=3.79\right.$, 


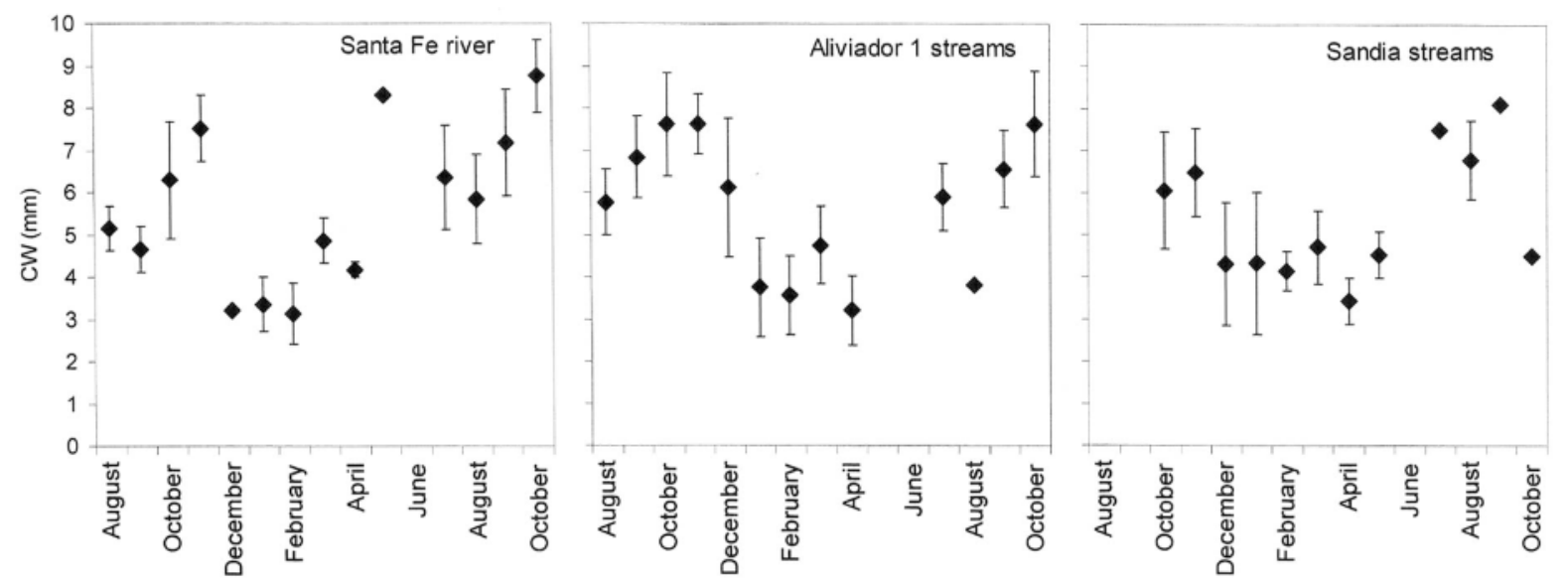

Fig. 4. Monthly size distribution of $T$. borellianus at the various sampling sites.

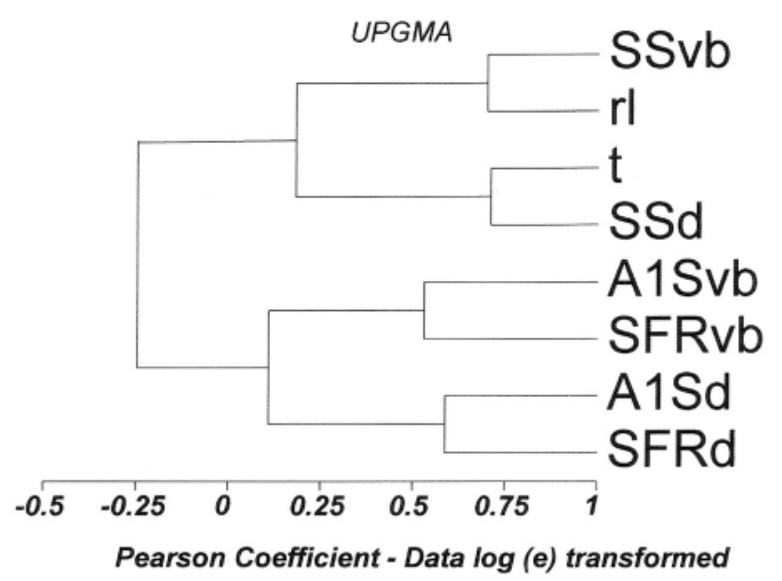

Fig. 5. Cluster analysis of T. borellianus density (d), vegetation biomass (vb), temperature (t) and river level (rl) using Pearson Product Moment Correlation Coefficient. Santa Fe River (SFR), Aliviador 1 stream (A1S), and Las Sandias stream (SS).

$\mathrm{p}=0.0021)$ with a similar arrangement in all three environments $\left(\mathrm{F}_{0.05}\right.$ (1), 2.38 $\left.=0.01, \mathrm{p}=0.9339\right)$ (Fig. 4). From mid-spring to mid-autumn juveniles were very frequent whereas adults predominated the rest of the year.

Total crab number (juveniles, males and females) in Las Sandias stream varied according to the level and temperature of the river (Fig. 5). However, at the sites located far from the main course of the Paraná river, the number of the crab and biomass of vegetation showed a high correlation (Fig. 5).

\section{Discussion}

Free-floating plants are the most productive aquatic macrophytes in the Paraná river alluvial valley. Studies of invertebrates that colonize these plants showed that $T$. borellianus is an important member of littoral communities (Poi de Neiff \& Neiff 1980). The presence of organisms may be considered as dependent on the habitat - vegetation characteristics (species, plant age), physico-chemical unsuitability, scarcity of food, prey presence- or sampling efficiency, as verified to other crustaceans (Poi de Neiff \& Carignan 1997, Berkenbush \& Rowden 1998, Lercari \& Defeo 1999, Pothoven et al. 2004). This study shows that the apparent temporal variation in the spatial distribution of the T. borellianus population differs among the three study sites, being a contagious distribution more frequent than in the case of other sympatric decapods (Williner \& Collins 2000). The bimodal frequency of the population found in the present study consisted of coexisting mature adults and juveniles. This characteristic may reflect different mortality rates between males and females and recruitment pulse, some types of behaviour, differential movements according to sex, and sex-specific habitat preferences (Díaz \& Conde 1989). In contrast, Trigueirinho Alarcon et al. (2002) found that T. fluviatilis showed a single mode in the size distribution of the population being this a characteristic of tropical and subtropical populations. Also, migration is common in marine crustaceans, but it is yet poorly known in freshwater decapods (Miquel et al. 1985, McClintock et al. 1993, Fernández \& Collins 2002). Therefore we can consider, as Bonetto (1976) and Sparks 
(1990) that the high water phase causes the resettlement of the systems. We can consider the recruitment of juvenile crabs as a phenomenon sign of the river level upward. Spatial heterogeneity is significant. Sites which are adjacent to the floodplain or separated by a few meters could differ in the number of days they remain connected to the main course and could have marked differences in the characteristics of the populations and communities (Thomaz et al. 1997). The systems with a flood pulse, such as rivers, behave as systems in a permanent imbalance, in which the temporal variability is a complex function dependent on the entrance and exit of energy and materials in different places of the basin and on the opportunities of the populations to adjust their distribution and abundance (Neiff 1990).

Males are more abundant during late winter and spring, coincidentally with the abundance of females in their ovaric maturation season. This suggests that males movements during these months are due to reproductive activity. A pattern of migration in which males precede females and juveniles in the reproductive displacement was evidenced in some marine crabs (Miquel et al. 1985) and other neotropical decapods (Fransozo et al. 2003). Sex rate variation could also be explained by the deaths of larger females as in other decapods (Spivak 1997). Moreover sex ratio might be attributed to the loss of large males from the population due to fighting or predation. Trichodactylus borellianus has been found to constitute an important prey species for birds, mammals and others animal groups (see Introduction). The abundance of crabs in aquatic macrophytes could affect the trophic relations by increasing the food available for other communities.

The spatial segregation between prey and predator could be due to the presence/absence of shelter or its availability (Williner \& Collins 2002). The influence of prey density, shelter, alternative prey presence and temperature could affect crab predation rate as in others crabs (Strieb et al. 1995). The roots of macrophytes and the base of the leaves of water hyacinth appeared therefore to be the best shelter for T. borellianus, while submerged macrophytes showed to be preferred by planktivorous fish. Roots are the most frequent shelter to piscivorous fish (Meerhoff et al. 2003), suggesting an antipredator behaviour for this crab species.

\section{References}

Berkenbusch K. \& Rowden A.A. 1998. - Population dynamics of the burrowing ghost shrimp Callianassa filholi on an intertidal sandflat in New Zealand. Ophelia, 49, 55-69.
Beltzer A.H. 1983. - Alimentación del "benteveo" (Pitangus sulphuratus) en el valle aluvial del río Paraná Medio (Passeriformes: Tyrannidae). Rev. Asoc. Cienc. Nat. Litoral, 14, 47-52.

Beltzer A.H. 1984. - Ecología alimentaria de Aramides ypecaha (Aves: Rallidae) en el valle aluvial del río Paraná Medio (Argentina). Rev. Asoc. Cienc. Nat. Litoral, 16, 73-83.

Beltzer A.H., Paporello G. 1984. - Alimentación de aves en el valle aluvial del río Paraná. IV Agelaius cyanopus cyanopus Vieillot, 1819 (Passeriformes: Icteridae). Iheringia Ser. Zool., 62, 55-60.

Bianchini J.J. \& Delupi L.H. 1993. - Mammalia. Fauna de Agua Dulce de la República Argentina. Vol. 44 (2), Ageitos de Castellanos Z (ed.) Buenos Aires, PROFADU, 79 p.

Bonetto A.A. 1976. - Calidad de las aguas del río Paraná. Introducción a su estudio ecológico. Dir. Nac. Constr. Port. y Vías Navegables. INCYTH-PNUD-ONU, Buenos Aires. 202 p.

Bonetto A.A. , Pignalberi C., Cordiviola E. 1963. - Ecología alimentaria del amarillo y moncholo, Pimelodus clarias (Bloch) y Pimelodus albicans (Valenciennes) (Pisces, Pimelodidae). Physis, 24, 87-94.

Bonetto A.A., Wais I.R. 1995. - Southern South American streams and rivers. Pages 257-293 in Ecosystems of the World 22: River and Stream Ecosystems. Cushing C.E., Cummins K.W. \& Minshall G.W. (eds). Elsevier, Amsterdam.

Bueno A. \& Bond-Buckup G. 2000. - Dinamica populacional de Aegla paltensis Schmitt (Crustacea, Anomura, Aeglidae). Revta. bras. Zool., 17, 43-49.

Díaz H. \& Conde J.E. 1989. - Population dynamics and life history of the mangrove crab Aratus pisonii (Brachyura, Grapsidae) in a marine environment. Bull. Mar. Sci., 45, 148-163.

Elliot, J.M. 1977. - Some Methods for the Statistical Analysis of Samples of Benthic Invertebrates. Freshwater Biological Association. Sci. Pub. $\mathrm{N}^{\circ}$. 25, 156 pp.

Fernandez D. \& Collins P.A. 2002. - Supervivencia de cangrejos en ambientes dulciacuicolas inestables. Nat. Neotrop., 33, 81-84.

Fransozo A., Costa R.C., Reigada A.L.D. \& Nakagaki J.M. 2003. Population structure of Aegla castro Schmitt, 1942 (Crustacea: Anomura: Aeglidae) from Itatinga (SP), Brazil. Acta Limnol. Bras., 15,13-20.

Giacosa R., Paoli C. \& Cacik P. 2000. - Conocimiento del régimen hidrológico. Pages: 69-103 in El río Paraná en su tramo medio. Contribución al conocimiento y prácticas ingenieriles en un gran río de llanura T1. Paoli C. \& Schreider M. (eds). Universidad Nacional del Litoral, Santa Fe.

Kovach W.L. 1998. - MVSP. A MultiVariate Statistical Package for Windows (version 3.0). Kovach Computing Services, Pentreth, Walles.

Lajmanovich R.C. \& Beltzer A.H. 1993. - Aporte al conocimiento de la biología alimentaria de la pollona negra Gallinula chloropus en el Paraná Medio, Argentina. El Hornero, 13, 289-291.

Lercari D. \& Defeo O. 1999. - Effects of freshwater discharge in Sandy beach populations: the mole crab Emerita brasiliensis in Uruguay. Estuarine Coastal Mar. Sci., 49, 457-468.

Lopretto E.C. 1976. - Morfología comparada de los pleópodos sexuales masculinos en los Trichodactylidae de la Argentina (Decapoda, Brachyura). Limnobios, 1, 67-94.

Lopretto E.C. 1995. - Crustacea Eumalacostraca. Pages 1001-1021 in Ecosistemas de aguas continentales, Vol.3. Lopretto E. \& Tell G. (eds). Ediciones Sur, La Plata.

Magalhães C. 2003. - Famílias Pseudothelphusidae e Trichodactylidae. Pages 143-287 in Manual de identificação dos Crustacea Decapoda de água doce do Brasil. Melo G. A. S. (ed.). Loyola, São Paulo.

Magalhães C. \& Türkay M. 1996. - Taxonomy of the neotropical freshwater crab family Trichodactylidae I. The generic system with 
description of some new genera. Senckenberg Biol., 75, 63-95.

Marta M.C. 1983. - Plantas acuáticas del litoral. Climax N³. ACNL (eds). Santo Tomé, 44p.

Massoia E. 1976. - Mammalia. Fauna de Agua Dulce de la República Argentina. Vol. 44 (2), Ageitos de Castellanos Z. (ed.) Buenos Aires, FECIC, $128 \mathrm{p}$

McClintock J.B., Marion K.R., Dindo J., Hsueh P.W. \& Angus R.A. 1993. - Population studies of blue crabs in soft-bottom, unvegetated habitats of a subestuary in the northern gulf of Mexico. $J$. Crustac. Biol., 13, 551-563.

Meerhoff M., Mazzeo N., Moss B., \& Rodriguez-Gallego L. 2003. The structuring role of free-floating versus submerged plants in a subtropical shallow lake. Aquat. Ecol., 37, 377-391.

Miquel J.C., Arnaud P.M., \& Do-Chi T. 1985. - Population structure and migration of the stone crab Lithodes murrayi in the Crozet Islands, Subantarctic Indian Ocean. Mar. Bio., 89, 263-269.

Morris D.W. 1996. - Temporal and spatial population dynamics among patches connected by habitat selection. Oikos, 75, 207 219 .

Neiff J.J. 1990. - Ideas para la interpretación ecológica del Paraná. Interciencia, 15, 424-441.

Oliva A., Ubeda C. A., Vignes I. E. Iriondo A. 1981. - Contribución al conocimiento de la ecología alimentaria del bagre amarillo ( $\mathrm{Pi}$ melodus maculatus Lacépède 1803) del río de la Plata (Pisces, Pimelodidae). Com. Mus. Arg. Cienc. Nat. Ecología, 1, 31-50.

Paoli C., Iriondo M., García N. 2000. - Caracteristicas de las cuencas de aporte. Pages 26-68 in El río Paraná en su tramo medio. Contribución al conocimiento y prácticas ingenieriles en un gran río de llanura T1. Paoli C. \& Schreider M. (eds). Universidad Nacional del Litoral, Santa Fe.

Paporello de Amsler G. 1987. - Fauna Asociada a las raíces de Eichhornia crassipes en una laguna del valle aluvial del río Paraná ("Los Matadores", Santa Fe, Argentina). Rev. Asoc. Cienc. Nat. Lit., 18, 93-103.

Poi de Neiff A., Bruquetas de Zozaya, I.Y. 1989. - Efecto de las crecidas sobre las poblaciones de invertebrados que habitan macrófitas emergentes en islas del río Paraná. Rev. Hydrobiol. Trop., 22 13-20.

Poi de Neiff A. \& Carignan R. 1997. - Macroinvertebrates on Eichhornia crassipes roots in two lakes of the Paraná river floodplain. Hydrobiologia, 345, 185-196.

Poi de Neiff A. \& Neiff J.J. 1980. - Los camalotales de Eichhornia crassipes en aguas lóticas del Paraná y su fauna asociada. Ecosur 7, 14, 185-199.

Pothoven S., Fahnenstiel G.L \& Vanderploeg H.A. 2004. - Spatial distribution, biomass and population dynamics of Mysis relicta in Lake Michigan. Hydrobiologia, 522, 291-299.
Ranta E., Kaitala V. \& Lundberg P. 1998. - Population variability in space and time: dynamics of synchronous population fluctuations. Oikos, 83, 376-382.

Ringuelet R. 1949. - Camarones y cangrejos de la zona de Goya (Sergestidae, Palaemonidae, Trichodactylinae). Notas del Museo de la Plata. Tomo XIV Zoología, N¹19. La Plata,129p.

Ruetz C.R., Trexler J.C., Jordan F., Loftus W.F. \& Perry S.A. 2005 Population dynamics of wetland fishes: spatio-temporal patterns synchronized by hydrological disturbance? J. Anim. Ecol., 74, 322-332.

Sparks R.E., Bayley P.B. Kohler S.L. \& Osborne L.L. 1990. - Disturbance and recovery of large floodplain rivers. Environ. Managem., 14, 699-709.

Spivak E.D. 1997. - Life history of a brackish-water population of Palaemonetes argentinus (Decapoda: Caridea) in Argentina. Annl. Limnol. - Int. J. Lim., 33, 179-190.

Strieb M.D., Bricelj V.M. \& Bauer S.I. 1995. - Population biology of the mud crab, Dyspanopeus sayi, an important predator of juvenile bay scallops in Long Islands (USA) Eelgrass beds. J. Shellfish Res., 14, 347-357.

Thomaz S.M., Roberto M.C. \& Bini L.M. 1997. - Caracterização limnológica dos ambientes aquáticos e influência dos níveis fluviométricos. Pages. 73-102 in A planicie de inundação do alto rio Paraná : aspectos físicos, biológicos e socioeconomicos Vazzoler A.E.A. de M., Agostinho A.A. \& Hahn N.S. (eds). EDUEM, Maringá.

Trigueirinho Alarcon D., Arruda Leme M.H. \& Cobo V.J. 2002. Population structure of the freshwater crab Trichodactylus fluviatilis Latreille, 1828 (Decapoda, Trichodactylidae) in Ubatuba, Northern coast of São Paulo state, Brazil. Pages 179-182 in Modern Approaches to the Study of crustaceans. Escobar-Briones E. \& Alvarez F. (eds). Kluwer Academic-Plenum Publishers, New York.

Williner V. \& Collins P.A. 2000. - Existe jerarquización en poblaciones de palemónidos del valle aluvial del río Paraná? Nat. Neotrop., 31, 53-60.

Williner V. \& Collins P.A. 2002. - Variación espacio -temporal de la actividad del camarón dulceacuícola Macrobrachium jelski (Miers, 1877) (Crustacea, Decapoda, Caridea, Palaemonidae). Ecología Austral, 12, 3-10.

Williner V. \& Collins P.A. 2002. - Daily rhythm of feeding activity of a freshwater crab Dilocarcinus pagei pagei in National Park Río Pilcomayo, Formosa, Argentina. Pages 171-178 in Modern approaches to the Study of Crustacea. Escobar-Briones E. \& Alvarez F. (eds). Kluwer Academic-Plenum Publishers, New York.

Zar J.H. 1996. - Biostatistical Analysis. Prentice Hall, New York, $662 \mathrm{p}$. 